Arab Univ. J. Agric. Sci., Ain Shams Univ., Cairo, 14(1), 173-193, 2006

\title{
EFFECT OF TILLAGE TREATMENTS AND INTERCROPPING PATTERNS ON WATER USE EFFICIENCY AND YEILD COMPONENTS OF SOYBEAN AND MAIZE
}

[11]

\author{
Sherif, Sahar $^{1}$. A.; Wafae Kh. Mohamed ${ }^{1}$; Sahar T. Ibrahim ${ }^{1}$; \\ H.E. Osman ${ }^{2}$ and S.I. El-Khatib ${ }^{2}$
}

\begin{abstract}
Two field experiments were performed at Sids Agriculture Farm Research Station, Bani Swif Governorate during 2003 and 2004 seasons, to study the suitability of different tillage treatments, i.e. chisel plough two and three passes at 10,15 and $20 \mathrm{~cm}$ depths and intercropping patterns of maize and soybean i.e. two ridges of maize : two ridges of soybean (2:2) and two ridges of maize : four ridges of soybean $(2: 4)$ on water consumption, growth characters, yield and quality of maize (cv. T.W.C. 310) intercropped with soybean (cv. Clark). The results indicated that using chisel plough 3 passes decreased the value of mean weight diameter (M.W.D) by $33.00 \%, 27.92 \%$ and $31.87 \%$ as compared when using chisel plough 2 passes for 10 , 15 and $20 \mathrm{~cm}$ depths respectively. On other hand, yield and quality of maize, as well as, yield and quality of soybean were significantly increased by using tillage with chisel plough 3 passes. Both yield of maize and soybean per feddan. in pure stand were always higher than those within any intercrop combination, these results were true in both seasons. The data also revealed that maize yield in $(2: 2)$ pattern and using chisel plough 3 passes at $15 \mathrm{~cm}$ depth gave the highest yield whereas, the highest yield of soybean per feddan was obtained when soybean plants grown in (2:4) pattern with 3 passes of chisel plough at $15 \mathrm{~cm}$ depth. On other hand the highest values of water use efficiency (W.U.E) in the two seasons were recorded when (2:4) pattern was applied and using chisel plough 3 passes at $15 \mathrm{~cm}$ depth The highest values of land equivalent ratio (LER) in the two seasons were 1.54 and 1.53 respectively when (2:4 ) pattern was applied.
\end{abstract}

Keywords: Intercropping patterns, Tillage systems, Maize, Soybean, Water applied

1- Field Crops Res. Inst. A.R.C., Giza, Egypt.

2- Agric. Eng. Res. Inst., A.R.C., Dokki, Giza, Egypt

(Received July 9, 2005)

(Accepted November 14, 2005) 


\section{INTRODUCTION}

Before sowing seeds it is necessary to prepare a suitable seedbed for seed germination. Tillage will ensure the adequate moisture and air quantity needed for plant. In addition the seedbed should be as free as possible from weeds and applied fertilizer be incorporated eventually with the soil. El-Nakib and Fouad, (1990) showed that the mean weight diameter (MWD) increased by increasing of working depth and forward speed because less breakdown would be produced at higher speed and depth. Abo-Habaga, (1992) concluded that decreasing the percentages of less than $(\varnothing>50 \mathrm{~mm})$ in the seedbed increased the main distance between adjacent seeds in row for a given number of seeds per unit area and then the crop yield was increased, on the other hand plant deviation percentage increased with large aggregates $(\varnothing 750 \mathrm{~mm})$. Also, he found that the best aggregate size diameters for drill machine was (Ø 20-50 $\mathrm{mm}$ ) for good germination and distribution. El-Hanafy et al (1995) reported that using the chisel plough followed by rotary plough for barley preparation land is considered the best combination to get the highest barley yield. Sherif et al (1995) indicated that tillage treatments significantly affected all characters studied i,e plant height, ear length, stem diameter, ear weight, weight of grains per ear, grain yield per plant, 100 grains weight and grain yield per fad except percentage of barren plants, number of ears per plant and number of rows per ear. He further added that no tillage treatment reduced grain yield as compared with conventional tillage.El-Douby et al (1996) concluded that the highest maize grain yield was obtained when
(4:2) intercropping pattern applied and maize was spaced at $20 \mathrm{~cm}$ apart in both seasons. Whereas, the highest soybean yield was produced with $(2: 4)$ intercropping pattern which included 33\% maize + $133 \%$ soybean in both seasons. They also added that intercropping increased "LER" values by $19 \%$ and $23 \%$ when $(2: 4)$ and (4:2) patterns when maize was sown at 20 $\mathrm{cm}$ apart in the first and second seasons, respectively. Shalaby, (1988) indicated that the effects of using chisel plough two passes followed by scraper, followed by wooden level $20 \mathrm{~cm}$ and chisel plough two passes followed by rotary plough once $20 \mathrm{~cm}$ gave high soil surface roughness of 35.30 and $32.60 \%$ and clod mean weight diameter of 40.12 and $36.48 \mathrm{~mm}$ respectively. While using chisel plough two passes followed by rotary plough 15 $\mathrm{cm}$ depth gave roughness of $25.20 \%$ and M.W.D. of $22.00 \mathrm{~mm}$. He also concluded that number of plants per $\mathrm{m}^{2}$ was affected greatly by soil profile and roughness. El-Khatib, (2000) summarized that the mean weight diameter (M.W.D.) after tillage with chisel plough one pass, chisel plough two passes and chisel plough two passes + disk harrow were 76.21, 60.23 and $43.35 \mathrm{~mm}$ respectively.

\section{MATERIAL AND METHODS}

Two field experiments were carried out at Sids Agricultural Farm Research Station Bani-Swif Governorate during 2003 and 2004 growing seasons, to study the effect of tillage systems and intercropping patterns on the amount of applied water, water use efficiency and yield of maize and soybean .A split plot design with three replicates was used, the main plots were allocated for tillage treatments whereas the sub plots were 
devoted for intercropping patterns. The sub- plot area was $42 \mathrm{~m}^{2}(7 \mathrm{~m} \times 6 \mathrm{~m})$ i.e 1 per100 feddan. The treatments were as follows:

\section{A. Tillage treatments}

1- Chisel plough 2 passes $(10,15$ and $20 \mathrm{~cm}$ depths).

2- Chisel plough 3 passes $(10,15$ and $20 \mathrm{~cm}$ depths).

\section{B. The intercropping treatments}

\section{The intercropping patterns were}

1- (2: 2) maize was grown on two ridges alternated with two ridges of soybean

2- (2: 4) maize was grown on two ridges alternated with four ridges of soybean

3- solid planting for both crops.

Soybean (cv. Clark) was seeded immediately after inoculation with Rhizobium bacteria to stimulate nodulation and irrigated at once. Seedling was carried out on $10^{\text {th }}$ May, 2003 and $15^{\text {th }}$ May, 2004 seasons. It was planted at $10 \mathrm{~cm}$ on both sides of all ridges and thinned to two plants per hole in all treatments. Maize (cv., Three Way Cross 310) was seeded at the first irrigation of soybean. It was seeded on $1^{\text {st }}$ and $10^{\text {th }}$ June, 2003 and 2004 seasons, at $30 \mathrm{~cm}$ apart and thinned to two plants / hill, whereas plants grown in pure stand were spaced at the same distances, but thinned to one plant / hill.

\section{C- The irrigation treatments}

The developed surface irrigation used in this investigation is a new technique to transmit irrigation water, by means of a pump, from the main source (open canal) to soil surface at the upper part of the field carrying water to be applied in the furrows through perforated 4-inch Aluminum line. Water meters of 0.1 cubic meter accuracy (to measure the amount of water applied) were attached to the network. The capacity of the used pump was up to $120 \mathrm{~m}^{3} /$ feddandan head. The pump was connected to the main line by flexible quick hitch hose. Irrigation was applied based on $40 \%$ of soil moisture content and evapotranspiration "ET ${ }_{\mathrm{p}}$ ". Frequency of irrigation was estimated described by Cuenca, (1989) as follows:

1- Total available moisture (TAW)

$$
\text { TAW = FC- CEW (1) }
$$

where

TAW is the total available moisture (mm per $\mathrm{m}$ ).

FC is field capacity

CEW is crop extractable water

2- Available moisture (AM) at $40 \%$ depletion

$\left(\mathrm{AM}_{40}\right)=\%$ depletion $\mathrm{x}$ TAW $\mathbf{x}$ root zone depth (2)

3- Frequency of irrigation $\left(\mathrm{I}_{\mathrm{fr}}\right)$

$$
I_{\text {fr }}=A_{40} \text { per } \mathbf{E t}_{\text {mgs }}(3)
$$

where: $\mathrm{Et}_{\mathrm{mgs}}$ is evapotranspiration at the midpoint of the growing season.

The quantity of water applied was estimated using the class A pan evaporation equation:

\section{$\operatorname{ETp}=\operatorname{Kp~Epam~(4)~}$}

Where

$\mathrm{ET}_{\mathrm{p}}=$ Evapo-transpiration of grass refrence crop, $\mathrm{mm}$ per $\mathrm{d}$

$\mathrm{K}_{\mathrm{p}}=$ pan coefficient

$\mathrm{E}_{\mathrm{pan}}=$ pan evaporation, $\mathrm{mm}$ per $\mathrm{d}$. 
The irrigation water was calculated on $100 \% \mathrm{ET}_{\mathrm{p}}$ basis and $100 \%$ water application efficiency, due to the even distribution of water within the strips and nonwater losses, as a result to precision land leveling by laser technology on the following basis:

1- The measured evaporation from the A pan between irrigation rounds.

2- A pan coefficient $=0.8$ for dry regions.

3- Average crop coefficient $=1$ for all stages of growth.

4- Evapo-transpiration Potential $\left(\mathrm{ET}_{\mathrm{p}}\right)$ $=100 \%$

Before starting the experimental, soil analysis was done. Table (1) shows the results of the mechanical analysis and the bulk density of the soil. Field capacity was $39.6 \%$ by weight and the wilting point was $18 \%$ by weight.

Each plot was fertilized with calcium superphosphate $\left(15.5 \% \mathrm{P}_{2} 0_{5}\right)$ at a rate of $150 \mathrm{~kg}$ per feddan. it was applied during land preparation and before planting. Potassic fertilizer was added in the form of potassium sulphate $\left(48 \% \mathrm{k}_{2} 0\right)$ at the second irrigation at a rate of $50 \mathrm{~kg} \mathrm{k}_{2} \mathrm{O}$ per feddan. $\mathrm{N}$ fertilizer as ammonium sulphate $(20.5 \% \mathrm{~N})$ was applied at a rate of $100 \mathrm{~kg} \mathrm{~N}$ per feddan. in 2 equal doses at the first and second irrigations. All the experimental treatments received the same agricultural practices as recommended.

\section{Measurement}

At harvest time ten plants were taken at random from the middle rows of each treatment to estimate growth characters, and quality of maize: plant height $\mathrm{cm}$, height of first ear $\mathrm{cm}$, ear length $\mathrm{cm}$, ear diameter $\mathrm{cm}$, average number of rows per ear, average number of kernels per row, weight of 100- grains.

Soybean: plant height $\mathrm{cm}$, average number of fruiting branches per plant, average number of pods per plant, weight of pods per plant, weight of 100 -seed.

Maize grain yield in $\mathrm{kg}$ per feddan as well as, yield of soybean in ton per feddan were calculated on hole plot basis.

\section{Methods of calculations}

\section{1-Water use efficiency "WUE" (kg per $\mathbf{m}^{3}$ )}

WUE = yield $(\mathrm{kg} / \mathrm{feddan})$ per total applied water $\left(\mathrm{m}^{3} /\right.$ feddan $)$

\section{2-Clod size distribution}

The mean weight diameter "MWD" was determined according Ashery, (1985) as follow

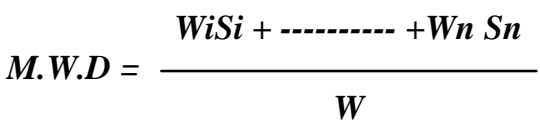

$$
M . W . D .=\frac{\Delta W 1 \Delta I}{W}
$$

Where: M.W.D. is mean weight diameter $(\mathrm{mm}), \mathrm{Wi}$ is soil weight on ith sieve, $\mathrm{Si}$ is sieve number (at first), $\mathrm{Wn}$ is soil weight on $\mathrm{Sn}, \mathrm{Sn}$ is sieve number (at last), $\mathrm{W}$ is total weight of soil sample, I is sieve number and $\Delta \mathrm{I}$ is $\mathrm{I}^{\text {th }}$ sieve mesh ( $\left.\mathrm{mm}\right)$. 
Table 1. Some physical properties of the experimental spoil

\begin{tabular}{|ccccccccc|}
\hline $\begin{array}{c}\text { Depth } \\
\mathrm{cm}\end{array}$ & $\begin{array}{c}\text { Coarse } \\
\text { sand } \%\end{array}$ & $\begin{array}{c}\text { Fine } \\
\text { sand } \\
\%\end{array}$ & $\begin{array}{c}\text { Silt } \\
\%\end{array}$ & $\begin{array}{c}\text { Clay } \\
\%\end{array}$ & $\begin{array}{c}\text { Texture } \\
\text { class }\end{array}$ & $\begin{array}{c}\text { Organic } \\
\text { matter } \\
\%\end{array}$ & $\begin{array}{c}\mathrm{CaCo}_{3} \\
\%\end{array}$ & $\begin{array}{c}\text { Bulk } \\
\text { density } \\
\mathrm{cm}^{3}\end{array}$ \\
\hline$(0-15)$ & 4.67 & 15.96 & 18.50 & 60.48 & Clay & 5.50 & 3.50 & 1.10 \\
$(15-30)$ & 4.50 & 13.50 & 19.00 & 63.00 & Clay & 5.00 & 4.0 & 1.09 \\
$(30-45)$ & 4.90 & 14.00 & 18.60 & 62.50 & Clay & 2.00 & 3.90 & 1.15 \\
$(45-60)$ & 3.50 & 15.50 & 16.00 & 65.00 & Clay & 2.00 & 3.50 & 1.15 \\
\hline
\end{tabular}

\section{3- Competitive relationships}

\section{1- Land equivalent ratio (LER)}

LER is determined as the sum of the fractions of the yield of the intercrops relative to their sole crop yields (Willey and Osiru, 1972). Land equivalent ratio LER was determined according to the following formula:

$$
L E R=\frac{Y_{a b}}{Y_{a a}}+\frac{Y_{b a}}{Y_{b b}}
$$

Where: $\mathrm{Y}_{\mathrm{aa}}$ is pure stand yield of species $\mathrm{a}, \mathrm{Y}_{\mathrm{bb}}$ is pure stand yield of species $\mathrm{b}, \mathrm{Y}_{\mathrm{ab}}$ is mixture yield of a (when combined with $b$ ) and $Y_{b a}$ is mixture yield of $b$ (when combined with a).

\section{2- Relative crowding coefficient (RCC)}

This was proposed according to Hall (1974). It assumes that mixture treatment forms a replacement series. Each series has its own coefficient $(\mathrm{K})$ which gives a measure to indicate that series has pro- duced more, less or equal yield to that expected. Relative crowding coefficient (RCC) was determined according to the following formula: for species (a) in a mixture with species (b).

$$
K_{a b}=\frac{Y_{a b} \times Z_{b a}}{\left(Y_{a a}-Y_{a b}\right) \times Z_{a b}}
$$

Where: $Z_{a b}$ is sown proportion of species a (in a mixture with $b$ ) and $Z_{b a}$ is sown proportion of species $b$ (in a mixture with a).

$$
K_{b a}=\frac{Y_{b a} \times Z_{a b}}{\left(Y_{b b}-Y_{b a}\right) \times Z_{b a}}
$$

If a species has a coefficient less than, equal to, or greater than 1, it means it has produced less yield, the same yield, or more yield than the "expected", respectively. The component crop with the higher coefficient is the dominant one. To determine if there is a yield advantage of mixing, the product of the coefficient is formed by multiplying $\mathrm{Kab} \mathrm{x} \mathrm{Kba}$. If $\mathrm{k}$ $>1$, there is a yield advantage, if $\mathrm{K}=1$ there is no difference and if $\mathrm{K}<1$ there is a yield disadvantage. 


\section{3- Aggressively (A)}

This parameter was proposed by Mc Gilichrist, (1960). It gives a simple measure of how much the relative yield increase in species (a) is greater than that of species (b). Aggressivity "A" is determined according to the following formula:

$$
\begin{gathered}
A_{a b}=\frac{\text { Mixture yield of } a}{\text { Expected yield of } a}-\frac{\text { Mixture yield of } b}{\text { Expected yield of } b} \\
A_{a b}=\frac{Y_{a} b}{Y_{a a} \times Z_{a b}}-\frac{Y_{b a}}{Y_{b b} \times Z_{b a}}
\end{gathered}
$$

An aggressively value of zero indicates that the component species are equally competitive. For any other situation, both species will have the same numerical value but the sign of the dominant species will be positive and the dominated negative. The greater the numerical value the bigger the difference in competitive abilities and the bigger the difference between actual and "expected" yield.

\section{RESULTS AND DISCUSSION}

\section{1- Effect of tillage passes and plough- ing depth on soil clods size distribu- tion}

Data in Table (2) showed that the highest percentage $(39 \%)$ of the largest soil clods size (more than $50 \mathrm{~mm}$ ) was obtained by tillage 2 passes with chisel plough at $20 \mathrm{~cm}$ depth. While the lowest percentage $(18 \%)$ was obtained by tillage
3 passes at $10 \mathrm{~cm}$ depth this may be due to increase the depth gave big aggregates and 2 passes gave less breakdown. The data revealed that using chisel plough 3 passes increased the percentage of small soil clods size (less than $50 \mathrm{~mm}$ ). Also, the data indicated that the differences in in M.W.D. were affected by tillage depth and tillage system. Using chisel plough 3 passes decreased the value of M.W.D. compared with using chisel plough 2 passes by $33.00 \%, 27.92 \%$ and $31.87 \%$ for 10,15 and $20 \mathrm{~cm}$ depths, respectively.

\section{2- Effect of tillage passes and plough- ing depth on water applied, water use efficiency, yield, and quality of maize intercropped with soybean}

Data on yield and quality as well as growth traits of maize are presented in Table (3). The data indicated significant differences, except in case of plant height (cm)., height of first ear $(\mathrm{cm})$, ear length (cm)., number of rows per ear in both seasons.

Tillage 2 passes with chisel plough at $15 \mathrm{~cm}$ depth gave lower quality as well as lower grain yield compared with tillage 3 passes at $15 \mathrm{~cm}$ depth in both seasons

On other hand, yield of maize increased by $10.50,12.28$ and $13.82 \%$ when chisel plough was done for 3 passes compared with 2 passes at 10, 15 and $20 \mathrm{~cm}$ depths respectively, in 2003 season and 6.46, 12.07 and $9.49 \%$ in 2004 season respectively. The higher yield was obtained by tillage 3 passes at $15 \mathrm{~cm}$ depth. These results were supported by those obtained by El-Sayed, (1983) who revealed that tillage using one pass of chisel plough was not suitable for mechanized planting where the surface of soil 
Table 2. Effect of tillage treatments on soil clods size distribution

\begin{tabular}{|ccccccc|}
\hline Tillage & Ploughing & \multicolumn{4}{c}{ Soil clods size distribution, \% } & M.W.D. \\
\cline { 3 - 6 } treatments & Depth, cm & $\begin{array}{c}5-10 \\
\mathrm{~mm}\end{array}$ & $\begin{array}{c}10-20 \\
\mathrm{~mm}\end{array}$ & $\begin{array}{c}20-50 \\
\mathrm{~mm}\end{array}$ & $\begin{array}{c}>50 \\
\mathrm{~mm}\end{array}$ & $\mathrm{~mm}$ \\
\hline Chisel & 10 & 17 & 21 & 37 & 25 & 30.12 \\
plough & 15 & 15 & 19 & 34 & 32 & 36.35 \\
2 passes & 20 & 10 & 16 & 35 & 39 & 41.80 \\
Chisel & 10 & 29 & 23 & 30 & 18 & 20.18 \\
plough & 15 & 17 & 28 & 33 & 22 & 26.20 \\
3 passes & 20 & 12 & 24 & 35 & 29 & 28.48 \\
\hline
\end{tabular}

Table 3. Effect of tillage passes and depth of ploughing on water applied, yield and quality, and water use efficiency of maize intercropped with soybean in 2003 and 2004 seasons

\begin{tabular}{|c|c|c|c|c|c|c|c|}
\hline \multirow{3}{*}{$\begin{array}{c}\text { Treatments } \\
\text { characters } \\
\text { depth }(\mathrm{cm})\end{array}$} & \multicolumn{6}{|c|}{2003 season } & \multirow{3}{*}{$\begin{array}{l}\text { LSD at } \\
0.05\end{array}$} \\
\hline & \multicolumn{3}{|c|}{ Chisel plough 2 passes } & \multicolumn{3}{|c|}{ Chisel plough 3passes } & \\
\hline & 10 & 15 & 20 & 10 & 15 & 20 & \\
\hline $\begin{array}{c}\text { Plant height } \\
(\mathrm{cm})\end{array}$ & 293.56 & 296.68 & 301.33 & 299.45 & 303.64 & 309.74 & N.S \\
\hline $\begin{array}{l}\text { Height of } 1^{\text {st }} \\
\text { ear }(\mathrm{cm})\end{array}$ & 80.37 & 86.07 & 88.83 & 91.93 & 93.43 & 97.33 & N.S \\
\hline $\begin{array}{l}\text { Ear length } \\
\quad(\mathrm{cm})\end{array}$ & 18.49 & 20.78 & 16.72 & 20.40 & 22.78 & 16.70 & N.S \\
\hline $\begin{array}{l}\text { Ear diameter } \\
(\mathrm{cm})\end{array}$ & 4.15 & 4.05 & 4.34 & 4.59 & 5.30 & 4.07 & 0.45 \\
\hline $\begin{array}{l}\text { Av. no. of } \\
\text { rowsper ear }\end{array}$ & 12.03 & 12.57 & 11.50 & 13.00 & 13.47 & 12.50 & N.S \\
\hline $\begin{array}{l}\text { Av. no. of } \\
\text { kernelsper } \\
\text { row }\end{array}$ & 40.96 & 45.98 & 37.94 & 44.99 & 48.91 & 41.40 & 1.61 \\
\hline $\begin{array}{l}\text { Wt. of 100- } \\
\text { grain (gm) }\end{array}$ & 30.27 & 32.70 & 29.73 & 35.40 & 38.93 & 31.53 & 2.28 \\
\hline $\begin{array}{c}\text { Yield } \\
\text { (kgperfad.) }\end{array}$ & 2443.33 & 2525.00 & 2306.67 & 2730.0 & 2878.33 & 2676.67 & 128.800 \\
\hline $\begin{array}{l}\text { Water applied } \\
\left(\mathrm{m}^{3} \text { perfad }\right)\end{array}$ & 2332.78 & 2366.11 & 2374.44 & 2377.78 & 2399.44 & 2418.89 & 11.30 \\
\hline $\begin{array}{c}\text { W.U.E }(\mathrm{kg} \\
\left.\text { per } \mathrm{m}^{3}\right)\end{array}$ & 1.05 & 1.07 & 0.97 & 1.15 & 1.20 & 1.11 & 0.035 \\
\hline
\end{tabular}

Arab Univ. J. Agric. Sci., 14(1), 2006 
Table 3. Cont.

\begin{tabular}{|c|c|c|c|c|c|c|c|}
\hline \multirow{3}{*}{$\begin{array}{c}\text { Treatments } \\
\text { characters } \\
\text { depth }(\mathrm{cm})\end{array}$} & \multicolumn{6}{|c|}{2004 season } & \multirow{3}{*}{$\begin{array}{l}\text { LSD at } \\
0.05\end{array}$} \\
\hline & \multicolumn{3}{|c|}{ Chisel plough 2 passes } & \multicolumn{3}{|c|}{ Chisel plough 3passes } & \\
\hline & 10 & 15 & 20 & 10 & 15 & 20 & \\
\hline $\begin{array}{l}\text { Plant height } \\
\text { (cm) }\end{array}$ & 285.22 & 289.77 & 293.96 & 290.54 & 298.11 & 303.50 & N.S \\
\hline $\begin{array}{l}\text { Height of } 1^{\text {st }} \\
\text { ear }(\mathrm{cm})\end{array}$ & 77.80 & 83.07 & 85.87 & 87.93 & 90.70 & 93.30 & N.S \\
\hline $\begin{array}{l}\text { Ear length } \\
\quad(\mathrm{cm})\end{array}$ & 18.91 & 20.60 & 15.62 & 19.67 & 21.17 & 17.53 & N.S \\
\hline $\begin{array}{l}\text { Ear diameter } \\
(\mathrm{cm})\end{array}$ & 4.53 & 4.80 & 3.85 & 4.55 & 5.27 & 4.13 & 0.79 \\
\hline $\begin{array}{l}\text { Av. no. of } \\
\text { row per ear }\end{array}$ & 11.30 & 11.90 & 10.67 & 11.83 & 12.17 & 11.23 & N.S \\
\hline $\begin{array}{l}\text { Av. no. of } \\
\text { kernelsper } \\
\text { row }\end{array}$ & 39.43 & 43.08 & 34.40 & 43.03 & 47.60 & 38.99 & 0.363 \\
\hline $\begin{array}{l}\text { Wt. of 100- } \\
\text { grain (gm) }\end{array}$ & 27.43 & 30.03 & 25.90 & 31.57 & 35.50 & 27.43 & 1.15 \\
\hline $\begin{array}{c}\text { Yield } \\
\text { (kgperfad) }\end{array}$ & 2365.00 & 2448.33 & 2226.67 & 2528.33 & 2784.33 & 2460.00 & 95.28 \\
\hline $\begin{array}{l}\text { Water applied } \\
\left(\mathrm{m}^{3} \text { perfad }\right)\end{array}$ & 2338.33 & 2350.11 & 2371.50 & 2380.33 & 2443.44 & 2480.89 & 17.59 \\
\hline $\begin{array}{c}\text { W.U.E } \\
\left(\mathrm{kg} \mathrm{perm}^{3}\right)\end{array}$ & 1.01 & 1.04 & 0.94 & 1.06 & 1.14 & 0.99 & 0.031 \\
\hline
\end{tabular}

being big clods and seed were not surrounded by uncompacted soil and lease bulk density.

Data in the same table, indicated that water applied $\left(\mathrm{m}^{3}\right.$ per fad) of maize were reduced by $(1.93,1.41$ and $1.87 \%)$ when chisel plough was done for 2 passes compared with 3 passes at depth at 10,15 and $20 \mathrm{~cm}$ respectively, in 2003 whereas, in 2004 season it was $(1.79,3.97$ and $4.61 \%$ ) for the same respective treatments. These results are in agreement with those obtained by El-Sayed, (1983) who found that the plant root system was small to catch up with water percolation through the soil. This lead to increase of water consumption in the deeply ploughed system. Also the W.U.E select the same trend and reduced by 9.52 , 12.15 and $14.43 \%$ in 2003 season whereas, in 2004 season it was 4.95, 9.62 and $5.34 \%$.

\section{3- Effect of intercropping patterns on water use efficiency, yield and its components of maize intercropped with soybean}

Data in Table (4) showed that growth of maize in monoculture was significantly higher than in other intercropping combinations. These results were supported by 
Table 4. Effect of intercropping patterns on WUE, yield, and its components of maize intercropped with soybean in 2003 and 2004 seasons

\begin{tabular}{|lcccc|}
\hline \multicolumn{1}{c}{ Intercropping patterns } & \multicolumn{3}{c}{ 2003 season } & LSD at \\
\cline { 2 - 4 } characters & $2: 2$ & $2: 4$ & solid & 0.05 \\
\hline Plant height (cm) & 295.20 & 301.23 & 305.81 & N.S \\
Height of 1 ${ }^{\text {st }}$ ear (cm) & 81.80 & 90.20 & 97.18 & 3.1 \\
Ear length (cm) & 16.84 & 19.13 & 21.96 & 0.632 \\
Ear diameter (cm) & 4.28 & 4.50 & 4.74 & 0.708 \\
Av. no. of rowsper ear & 12.42 & 12.53 & 13.03 & N.S \\
Av. no. of kernelsper row & 39.56 & 46.83 & 48.50 & 1.97 \\
Wt. of 100-grain ( gm) & 29.25 & 32.53 & 36.90 & 3.30 \\
Yield (kgperfad) & 2577.50 & 2260.83 & 2941.67 & 502.0 \\
Water applied (m ${ }^{3}$ perfad) & 2449.44 & 2397.11 & 2338.67 & 15.75 \\
W.U.E (kg per m ${ }^{3}$ ) & 1.05 & 0.94 & 1.26 & 0.033 \\
\hline
\end{tabular}

Table 4. Cont.

\begin{tabular}{|lcccc|}
\hline \multicolumn{1}{c}{ Intercropping patterns } & \multicolumn{3}{c}{ 2004 season } & LSD at \\
\cline { 2 - 4 } characters & $2: 2$ & $2: 4$ & solid & 0.05 \\
\hline Plant height $(\mathrm{cm})$ & 288.52 & 294.34 & 297.69 & N.S \\
Height of 1 ${ }^{\text {st }}$ ear $(\mathrm{cm})$ & 78.58 & 86.72 & 93.43 & 2.75 \\
Ear length (cm) & 17.69 & 18.42 & 20.73 & 0.607 \\
Ear diameter (cm) & 4.25 & 4.44 & 4.88 & 0.519 \\
Av. no. of rowsper ear & 10.97 & 11.58 & 12.15 & N.S \\
Av. no. of kernelsper row & 37.99 & 40.69 & 44.58 & 0.942 \\
Wt. of 100-grain (gm) & 26.37 & 29.30 & 33.27 & 4.61 \\
Yield (kgperfad) & 2500.50 & 2122.50 & 2791.67 & 421.40 \\
Water applied $\left(\mathrm{m}^{3}\right.$ perfad) & 2456.67 & 2372.00 & 2348.57 & 20.33 \\
W.U.E $\left(\mathrm{kg}\right.$ per $\left.\mathrm{m}^{3}\right)$ & 1.02 & 0.89 & 1.19 & 0.022 \\
\hline
\end{tabular}


those obtained by Kamel et al (1990) and El-Douby, (1992). The detrimental effect of intercropping on growth characters of maize plants may be due to the increase in plant density per unit area of both components. Maize density was estimated to $67 \%$ of maize Population in solid planting when maize was intercropped with soybean in $(2: 4)$ pattern. The adverse effects appeared more conspicions when maize grown in $(2: 2)$ pattern. This is attributed more to inter and intra competition between plants as a result of the heavy density of plants per unit area.

Data on maize quality indicted clearly that ear length, number of rows per ear, number of kernels per row and weight of 100 grains of solid planting were superior to those in all intercrop associations, except, in case of average number of kernels per row in (2:4) pattern in 2003 season. However, estimated values for all traits of maize plants grown in (2:4) pattern were higher than those plants grown in (2:2) pattern. Kamel et al (1990) found that yield of maize grown in $(2: 2)$ pattern was higher than those grown in $(2: 4)$ pattern. It seemed that maize yield in the intercrop combination was closely parallel to maize density, interpreting superiority of maize yield in (2:2) pattern over that in (2:4) pattern.

Data on yield of grains per Fadden showed that none of the intercropping patterns was able to give yield equal to or more than solid maize treatment. The estimated excesses in yield of solid maize treatment over (2:2) and (2:4) patterns were 12.38 and $23.15 \%$ in 2003 season and 10.43 and $23.97 \%$ in 2004 season respectively. Several investigators verified these results Kamel $\boldsymbol{e t} \boldsymbol{a l}$ (1990) and El-Douby (1992).
On other hand, the data revealed that the water applied increased by 4.52 and $2.44 \%$ over those in pure stand when intercropping patterns $(2: 2$ and $2: 4)$ were applied in 2003 season respectively whereas, in 2004 season it was 4.40 and $1.00 \%$ for the same respective patterns. When the highest water use efficiency was obtained when maize grown in pure stand than those grown under different intercropping combinations it was reduced by $(20.00$ and $34.04 \%)$ when $(2: 2$ and 2:4) patterns were applied in 2003 season. In 2004 season the reduction was (16.67 and $33.71 \%$ ) for the same selective patterns. These results were supported by El-Khatib and Sherif, (2003).

\section{4- Interaction effect of tillage treat- ments, depth of ploughing and in- tercropping patterns on water ap- plied, yield and quality of maize in- tercropped with soybean}

The interaction effect of tillage treatments and intercropping patterns on growth, yield and quality and water applied of maize is presented in Table (5). Data indicated that differences between treatments were not great enough to reach the $5 \%$ level of significance, except in case of ear diameter and water applied in 2003 and 2004 seasons and ear length in 2004 season. Moreover, maximum plant height and height of first ear were obtained when maize plants were grown in pure stand and ploughed 3 passes with the chisel plough at $20 \mathrm{~cm}$ depth, whereas minimum values were obtained in $(2: 2)$ pattern and chisel plough was done 2 passes at $10 \mathrm{~cm}$ depth..

The interaction effect on maize yield per feddan was relatively influenced by maize population. However, none of the 
184 Sahar Sherif; Wafae Mohamed; Sahar Ibrahim; Osman and El-Khatib

Arab Univ. J. Agric. Sci., 14(1), 2006 
intercropping patterns exceeded the pure stand. The excess in yield of maize grown in pure stand and ploughed 3 passes at $15 \mathrm{~cm}$ depth over those grown in $(2: 2)$ pattern was 5.56 and $3.28 \%$ in 2003 and 2004 seasons respectively, whereas, the excess over those grown in $(2: 4)$ pattern was 15.40 and $22.95 \%$ in 2003 and 2004 seasons, respectively.

In addition, maximum value of WUE was obtained when maize plants were grown in pure stand and ploughed 3 passes at a depth of $15 \mathrm{~cm}$ whereas, the minimum values were obtained when plants were grown in (2:4) pattern and ploughed 2 passes at a depth of $30 \mathrm{~cm}$ in the both seasons.

\section{5- Effect of tillage systems treatments on water applied, water use efficien- cy, yield and quality of soybean in- tercropped with maize}

Data in Table (6) showed that soybean growth characters, yield and quality were affected by increasing tillage passes and ploughing depth. These results were true in cases of plant height, number of branches per plant, water applied in both seasons. Ploughing 3 passes at $15 \mathrm{~cm}$ depth gave higher quality as well as higher grain yield compared with other treatments in both seasons, except in case of number of podsperplant in both seasons.

On other hand, data revealed that the yield of soybean increased by 15.18 , 12.48 and $13.32 \%$ when ploughing 3 passes with chisel ploughs compared with 2 passes at 10,15 and $20 \mathrm{~cm}$ depths in 2003 season, respectively and 18.64, 15.30 and $15.72 \%$ in 2004 season respectively. It is clear that higher yield of soybean was obtained when soybean plants were grown under 3 passes with chisel plough at $15 \mathrm{~cm}$ depth in both seasons.

Data in the same table indicated that the water use efficiency $\left(\mathrm{kg}\right.$ per $\left.\mathrm{m}^{3}\right)$ of soybean has the higher value when ploughing 3 passes at $15 \mathrm{~cm}$ depth in both seasons. These results are in agree with those obtained by El-Sayed, (1983).

\section{6- Effect of intercropping patterns on yield and quality of soybean inter- cropped with maize}

Data in Table (7) showed significant effects on plant height, average number of pods per plant in both seasons. However data analysis showed that soybean growth in pure stand was significantly higher than on other any intercrop combinations. In addition, values of growth characters of soybean grown in (2:4) pattern were mostly higher than those obtained in (2:2) pattern. Growing two rows of maize alternated with four rows of soybean had the highest values, whereas in case of two rows of maize alternated with two rows of soybean possessed the least values. These results are in agreement with those obtained by Kamel $\boldsymbol{e t}$ al (1990). They revealed a general tendency towards more growth vigor and weight when plants grow in row strip alternated with two rows of maize. However, the general increase in growth characters of soybean plants grown in (2:4) pattern may be due to more light intercepted by foliage as well as the low below and above ground competition between both components in the mixture. On other hand, the minimum growth values were associated with (2:2) pattern may be due to low light intensity owing to the shade of maize plants. 
186 Sahar Sherif; Wafae Mohamed; Sahar Ibrahim; Osman and El-Khatib

Arab Univ. J. Agric. Sci., 14(1), 2006 
Arab Univ. J. Agric. Sci., 14(1), 2006 
Data revealed that yield of soybean in pure stand in the two seasons were significantly higher than that grown in $(2: 2)$ pattern as well as those grown in $(2: 4)$ pattern.

In this respect, Kamel et al (1990) reported that increases in yield of soybean were closely parallel with the increases of soybean ratio in the intercrop pattern. Increases in soybean yield associated with (2:4) may be related to the increase in soybean population as compared with (2:2) pattern.

The data also indicated that the highest WUE were obtained when soybean was grown in pure stand than in $2: 2$ and 2:4) patterns in both seasons. Whereas the heighest value of water applied was obtained when soybean was grown in (2:2) pattern. These results are in agreement with those obtained by El-Khatib and Sahar (2003).

\section{7- Interaction effect of intercropping patterns and tillage treatments on water applied, WUE, yield and quality of soybean}

The interaction effect of tillage treatments and intercropping patterns on WUE, water applied, yield and quality of soybean were not significant except in cases of plant height and yield per feddan in the second season, as well as, water applied and WUE in both seasons presented in Table (8). Values of yield and quality of soybean plants in (2:4) pattern were relatively superior to that in $(2: 2)$ pattern. None of the intercrop combinations exceeded the solid planting of soybean under any treatment of tillage system. It is also clear that the highest yield of soybean in the intercrop combinations was obtained with (2:4) pattern and ploughing with chisel plough 3 passes at $15 \mathrm{~cm}$ depth, whereas the least yield was associated with (2:2) pattern and ploughing with chisel plough 2 passes at $20 \mathrm{~cm}$ depth.

Moreover, it is evident that maximum value of WUE was obtained when soybean plants were grown in pure stand and ploughing with chisel plough 3 passes whereas the minimum values were obtained when plants were grown in $(2: 2)$ pattern and ploughing with chisel plough 2 passes.

\section{8- Competitive relationships}

Intercropping patterns exhibited effects on the relative yield of maize, as well as, the RY of soybean (Table 9). Highest RY value for maize was obtained in (2:2) pattern. These results seemed coincided with maize densities in the mixture. Kamel et al (1990) came to a similar conclusion. Highest RY value of soybean was obtained with $(2: 4)$ pattern. This increase in RY was associated with the increase of soybean population in the mixture. Results indicated that the highest LER value was obtained when both crops were oriented in $(2: 4)$ pattern. The reduction in LER associated with $(2: 2)$ pattern were 7.14 and 7.12 below LER values for (2:4) in both seasons respectively.

Relative crowding coeffient (RCC) followed a similar trend as in LER (Table 9). K and the total RCC values were superior when both components were oriented in (2:4) pattern. Results hold true in both seasons. Sveral investigators supported these results such as Kamel $\boldsymbol{e t}$ al (1990) and Sherif (1993). 
Arab Univ. J. Agric. Sci., 14(1), 2006 
190 Sahar Sherif; Wafae Mohamed; Sahar Ibrahim; Osman and El-Khatib

Arab Univ. J. Agric. Sci., 14(1), 2006 
Table 9. Effect of intercropping patterns on competitive relationships in 2003 and 2004 seasons

\begin{tabular}{|c|c|c|c|c|c|c|c|c|}
\hline \multirow{3}{*}{ Treatments } & \multicolumn{8}{|c|}{2003 season } \\
\hline & \multicolumn{2}{|c|}{ RY } & \multirow{2}{*}{ LER } & \multicolumn{2}{|c|}{$\mathrm{K}$} & \multirow{2}{*}{$\mathrm{RCC}$} & \multicolumn{2}{|c|}{ Agg } \\
\hline & Maize & soybean & & maize & soybean & & maize & soybean \\
\hline $2: 2$ & 0.88 & 0.55 & 1.43 & 7.08 & 1.20 & 8.50 & +0.66 & -0.66 \\
\hline \multirow[t]{2}{*}{$2: 4$} & 0.77 & 0.77 & 1.54 & 6.74 & 1.62 & 10.92 & +1.19 & -1.19 \\
\hline & \multicolumn{8}{|c|}{2004 season } \\
\hline $2: 2$ & 0.90 & 0.52 & 1.42 & 8.59 & 1.08 & 9.28 & +0.75 & -0.75 \\
\hline $2: 4$ & 0.76 & 0.77 & 1.53 & 6.44 & 1.62 & 10.43 & +1.16 & -1.16 \\
\hline
\end{tabular}

Data on aggressively (Agg). revealed that the least value was associated with (2:2) pattern. Moreover, maize was always the dominant component while soybean was the dominated in all intercrop combinations in both seasons. These results were concordant with those obtained by Attia and El-Bially, (1990)

\section{REFERENCES}

Abo-Habaga, M.M. (1992). Influence of Soil Clods Size Distribution in Seedbed on the Applicability of a Grain Drill Machine for Wheat. Misr J. Agric. Eng. 9(1): 58-66.

Ashery, E.S.R (1985). Development of the Locally Made Chisel Plough pp. 7374. M.Sc. Thesis., Fac. Agric., Saba Basha, Alex. Univ., Egypt.

Attia, A.M. and M.E. El-Bially (1990). Interspecific competition and yield adventage of some summer crops as affected by some intercropping patterns and nitrogen rates. Proc. $4^{\text {th }}$ Conf. Agron. Cairo, Vol. II: 613-625.
Cuenca, R.H. (1989). Irrigation System Design: An Engineering Approach. pp. 120-125.Prentice-Hall, Englewood Cliffs, NJ.

El-Douby, A.K. (1992). Responses of Maize Grain Yield to Different Intercropping Patterns pp. 192-197. Ph. D. Thesis, Fac. Agric., Moshtohor, Zagazig Univ., Egypt.

El-Douby, A.K.; K.E. El-Habbak; H.E. Khalil and Zahira M. Attia (1996). Effect of some intercropping patterns on grpwth and yield of maize and soybean. Annals of Agric. Sci., Moshtohor, 34(3): 919-933.

El-Hanafy, E.H.; H. Abd-Alla and S.M. Radwan (1995). Effect of Some Seedbed Preparation on Seed Drill Performance, Soil Physical Properaties and Barely Yield. Misr J. Agric. Eng., 12(3): 591600.

El-Khatib, S.I. (2000). Effect of Tillage System on Laser Land Leveling Efficiency. Arab Univ. J. Agric Sci., Ain Shams Univ., Cairo, 8(1): 31-40.

El-Khatib, S.I. and Sahar A.M. Sherif (2003). Effect of Soybean - Maize Inter- 
cropping and Laser Land Leveling on Water Use Efficiency, Plant Growth, Yield and Total Net Return, Egypt, J. Agric. Res., 81(2): 699-717.

El-Nakib, A.A. and H.A. Fouad (1990). Effect of Minimum Tillage With Conditioner Implement On Soil Physical Properties. Miser J. Agric. Eng.7(2):121-131. El-Sayed, G.H. (1983). Mechanized Techniques for Suitable Seedbed Preparation and Planting of Maize, pp. 60-73 M.Sc. Faculty of Agric. Agric Eng. Department, Zagazig Univeristy, Egypt

Hall, R.L. (1974). Analysis of the nature of niterfrence between plants of different species. Aust. J. Agric. Res., 25:749-756.

Kamel, A.S.; M.N. Sherif; M.A. El-Masry; S.K. Badr and M.A. AbdEl-Aziz (1990). Intercropping maize with soybean as influenced by different patterns. Agric. Rev. 28(1): 1-19.

Mc Gilichrist, C.A. (1960). Analysis and competition experiments Biometrics, 21: 975-985.
Shalaby, S.A. (1988). Effect of Seed bed Preparation Systems on Wheat Transplanting, pp. 105-109. M.Sc. Thesis, Faculty of Agric., Mansoura Univ., Egypt.

Sahar, A.M. Sherif (1993). Studies on Fertilizer Requirements under Different Patterns of Soybean - Maize Intercropping under Some African Environmental Conditions pp. 88-96. M.Sc. Institute of African research and studies. Natural Resources Department Cairo University, Cairo.

Sherif, M.N.; S.K. Badr and A.M. Aly (1995). Effect of Some Preceding Winter Crops And Tillage on Growth, Yield And Quality of Maize. Egypt. J. Applied Sci.; 10 (12): 127 - 138.

Willey, R.W. and S.O. Osiru (1972). Studies on mixture of maize and beans (phasolus vulgaris) with particular refrence to plant populations. J. Agric. Sci. Cambridge, 79: 519-529. 


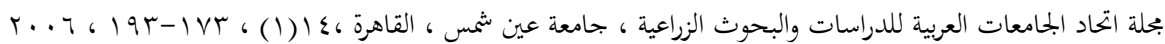

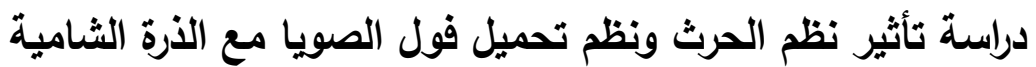

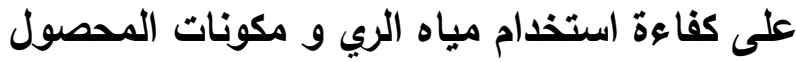

[11]

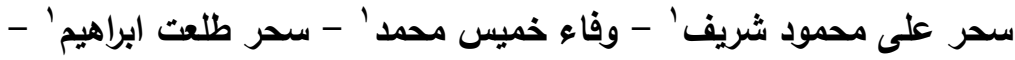

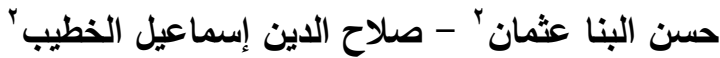

- قسم التكثيف المحصولى - معهد بحوث المحاصيل الحقلية - مركز البحوث الزراعية - الجيزة- مصر

r - معهد بحـوث الهندسة الزراعيـة - مركز البحـوث الزراعية - الدقى - الجيزة- مصر مرك

أجريت تجربتان حقليتان بمحطة بحوث كما أشـارت البيانـات الى أن محصول

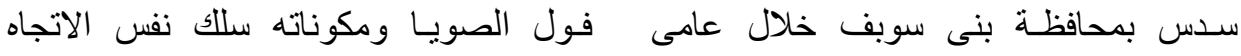

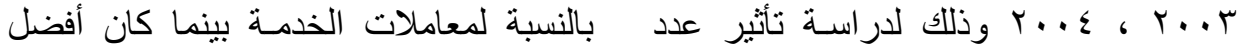

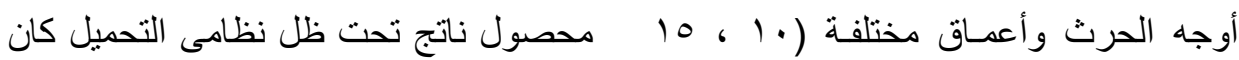

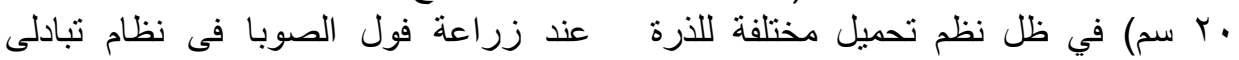

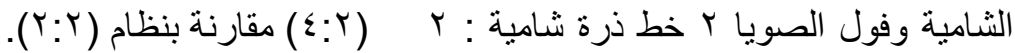

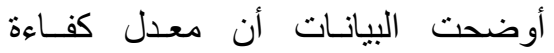

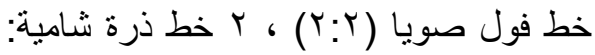

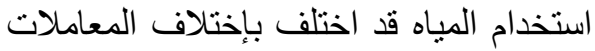

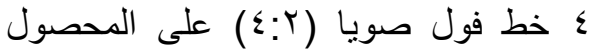

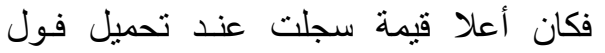

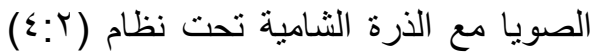
والحرث بثثلاثة أوجه مع عمق الثمانة 0 اسم نظم

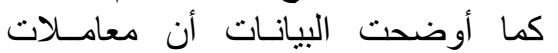

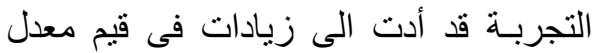

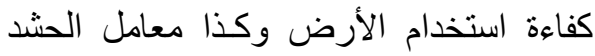

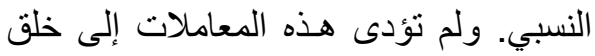

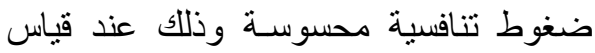

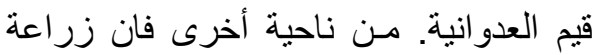

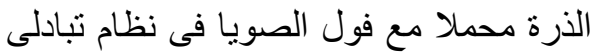

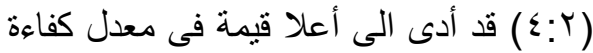

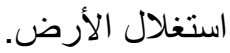

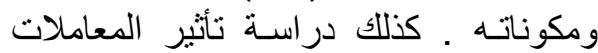

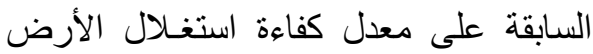

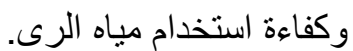

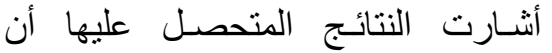

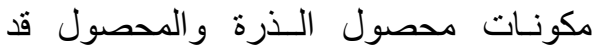

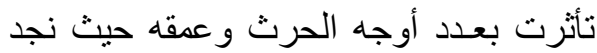

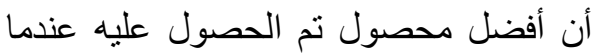

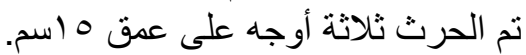

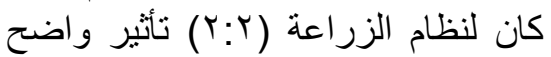

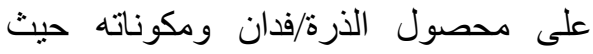

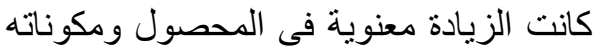

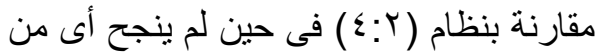

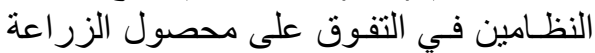
النقية . تحكيم: أ.د عبد الغنى الجندى أ.د محمد عباس المصرى 